\title{
Chen Zhifo's Contributions to Chinese Modern Art Education
}

\author{
Jianli $\mathrm{Li}^{1, *}$ \\ ${ }^{1}$ College of Art and Design, Wuhan Textile University, Wuhan, Hubei 430073, China \\ *Corresponding author. Email:1227592515@qq.com
}

\begin{abstract}
Chen Zhifo is a famous master of Chinese meticulous flowers-and-birds painting in modern times, as well as a famous art theorist and modern art educator. This paper mainly elaborates Chen Zhifo's contribution to the development of national art education and pattern design education in art education throughout his life. Through reading literature and related materials, it understands his ideological proposition that emphasizes the principle of arts and crafts design in design, and clarifies the main characteristics of arts and crafts design in practice. Chen Zhifo is the leader of Chinese modern arts and crafts education and the founder of Chinese modern design. He has a profound influence on the development of Chinese modern design education.
\end{abstract}

\section{Keywords: pattern design, arts and crafts education, educational contribution}

\section{INTRODUCTION}

In recent years, research on Chen Zhifo's contribution to Chinese modern art has generally focused on his contribution to pattern art design and his outstanding contribution to meticulous flowers-andbirds painting. Few people have conducted in-depth research on his contribution to Chinese art education and craft design education. In order to explore Chen Zhifo's contribution to Chinese art education, this paper will start from Chen Zhifo's learning and teaching experience, discovers his special contribution to Chinese art education, and understands his design education thoughts and his important contributions to Chinese arts and crafts design.

\section{A PIONEER IN LEARNING MODERN ARTS} AND CRAFTS

\section{A. The accumulation of early enlightenment painting}

Chen Zhifo was born in a feudal wealthy landlord family in Xiaojili, Dongmen, Yuyao County, Zhejiang Province in the 22nd year of the reign of Emperor Guang Xu, Qing Dynasty. At that time, at the late Qing Dynasty and the early Republic of China, warlords in various regions were rampant, wars were raging, and the whole society was in turmoil. Chen Zhifo's original name was Chen Shaoben, and later he used Zhifo as his name. In the later period, he named himself Xueweng when he studied the meticulous flowers-and-birds painting. When Chen Zhifo was a child, he had a good family background. Influenced by the New Culture Movement, he received a new-style school education that was completely different from feudal private schools. The young Chen Zhifo began to receive the influence of science and democratic thoughts. When Chen Zhifo was a child, he was clever and smart. He loved graffiti and painting. When he was a young boy, he found the "Painting Manual of the Mustard Seed Garden" in his granduncle's home collection. This book concentrates on the concentrated summary of brushwork, modeling, and painting and art of composition by some ancient painters, which can be said to be an important book for Chen Zhifo's painting enlightenment. Later, due to social turmoil, Chen Zhifo's family fortunes declined. However, he studied hard and achieved excellent results, and was admitted to Zhejiang Industrial School. During the academic year, Chen Zhifo received systematic painting training. He studied assiduously and could draw inferences about other cases from one instance, and as a result, his painting skills and cultural accomplishments were improved. Because of his outstanding performance, he stayed at school to teach for two years after graduation. However, knowledge is infinite. In order to continue his studies, he was admitted as a Japanese overseas student with official fee in 1918.

\section{B. All-round development after his studying in Japan}

After Chen Zhifo went to Japan to study, he was recommended by Mr. Rong Changji to study watercolor and gouache with the famous Japanese watercolor painter Katsumi Miyake. The studious and hardworking Chen Zhifo not only studied watercolor painting with Mr. Katsumi Miyake, but also studied drawing at the Hakuba Society Western Painting Research Institute at that time, and also studied body painting in the studio 
of Western painter Yasuda. The Tokyo Academy of Fine Arts that Chen Zhifo was admitted was the highest art school in Japan at the time. Only the Fine Arts Department recruited foreign students. At that time, most Chinese students studied oil painting. The Craft Department of Tokyo Academy of Fine Arts, as a secret subject for Japanese military industry, never recruits foreign students because of its strict professional restrictions and national restrictions. However, Chen Zhifo was unwilling to study only general painting art such as Western oil painting. He wanted to enter the Craft Department of the college for more in-depth study. With a tenacious and hard-working will, Chen Zhifo lived up to his mission and was admitted to the Arts and Crafts Department of Tokyo Academy of Fine Arts with excellent results. He became the first foreign student in the Arts and Crafts Department of the school, and the first Chinese to study art and design in Japan at public expense. While in school, Chen Zhifo was accepted by Professor Shimada Yoshiki, who is called the "Godfather of Pattern Method" in Japan. Professor Shimada Yoshiki paid great attention to Chen Zhifo's academic work, and guided Chen Zhifo to integrate pattern design with Chinese national cultural characteristics and carry forward the excellent essence of national tradition. Under the influence of the professor's guidance, Chen Zhifo combined Chinese national style with pattern design and designed many wonderful color patterns.

\section{A PATHFINDER EXPLORING MODERN ARTS AND CRAFTS EDUCATION}

\section{A. Developing national art education}

After returning from Japan, Chen Zhifo was hired as an art lecturer by the Shanghai Oriental Art Academy at that time. His more than forty years of college teaching career also began here. At the same time, he also started a lifelong education career. In most famous colleges and universities in the history of Chinese modern art development, Chen Zhifo have participated in almost all the teaching activities and research construction of these schools. Not only that, he was also committed to the development of Chinese art, and actively participated in the preparation of the first National Art Exhibition in 1928 and its review work. Moreover, with the joint efforts of Chen Zhifo and other art workers, the China Art Association was established, the art museum was founded, and the first art exhibition of the China Art Association was successfully held in 1934, and then the Chinese Art History Association was established. All of them are of great significance to sort out and study the history of Chinese art. After the founding of New China, Chen Zhifo vigorously developed art education in Jiangsu, Zhejiang and even the whole country. The task of art education became more onerous, and he had more positions. This also meant that he had to devote more energy and effort to Chinese art education.

\section{B. Developing pattern design education}

At the beginning of the 20th century, China was facing domestic strife and foreign aggression. The national industry was disintegrated by the impact of the western industrial revolution, and the invasion of foreign factories caused a great impact on some local handicraft production workshops in China. Although the Qing Government learned from the west to carry out the Westernization Movement to save national industries, the overall social productivity level at that time was low. Although there were some spinning mills founded by Zhang Zhidong in Hubei and Nanyang Brothers' tobacco companies, the industry was not able to achieve real development due to the lack of pattern design or advertising design in line with the product itself. In this situation where the production relationship and the product design were extremely mismatched, Chen Zhifo, as the first batch of international students who graduated from the Craft Department of Tokyo Academy of Fine Arts returning to Shanghai, was very popular. After returning to China, Chen Zhifo was hired as an art lecturer by Shanghai Oriental Art Academy, and at the same time, he also taught pattern lessons in other art colleges. Although Chen Zhifo was a teacher in school, as a Chinese who loved his motherland, he deeply felt the importance of pattern design for the future development of arts and crafts design, so he raised funds and founded Shangmei Pattern Pavilion. Due to lack of funds, Chen Zhifo set up the Shangmei Pattern Pavilion in his apartment. His apartment was not only a pattern house but also a studio for his drawing, and it often gave material assistance to his students, relatives and friends. The Shangmei Pattern Pavilion only managed to be operated for two years under such simple and limited circumstances. The past two years of operation of the Shangmei Pattern Pavilion witnessed the process of Chen Zhifo's promoting modern design practice in Shanghai after graduation. Although it was operated only two years, Shangmei Pattern Pavilion should be the first independent design agency in modern China that directly connected with industrial production and directly served the industrial manufacturing process.

\section{Emphasizing the principle of arts and crafts design}

Mr. Chen Zhifo believed that three principles of design should also be followed in the arts and crafts design. The first is applicability. Everyone knows that the first consideration in product design is applicability and scope of application. If a product is designed to be extremely gorgeous and uses many materials and processes, but it is not suitable for the objects it serves, then the design itself is a failure, which is not only a waste of materials, but also not practical. The second is 
economy. In process design creation, the cost of the design must be considered. If a lot of manpower and material resources are spent to purely pursue the application and aesthetics, and ignore the cost calculation, the design will also fail. The third is the principle of aesthetics. In addition to paying attention to applicability and economy, aesthetics must be emphasized in the design. If you only consider cost and applicability and ignore aesthetics, this will not work, either. Chen Zhifo believes that these three design principles are not isolated from each other. Applicability, economy and aesthetics are organically unified. It is not good to only pay attention to applicability and economy and ignore the aesthetics. It is also impractical if it is not artistic, which is undoubtedly abandoning the beauty of the design, just like a beauty who has a sick eye and a strong man breaks one arm. If you only focus on aesthetics and ignore the applicability and economy, it will not work either. Chen Zhifo believes that the inapplicable and the uneconomical are inaesthetic, and believes that the three must be organically unified and combined in the design, so that the products designed can truly meet the needs of the public.

\section{Clarifying the main characteristics of arts and crafts design}

In many of Chen Zhifo's works, it can be understood that the main characteristics of arts and crafts that Mr. Chen Zhifo said are skill, regionality and nationality. Skill represents to a certain extent manual creation. First of all, arts and crafts design pay attention to technology and handicrafts, and arts and crafts designers must have a high level of knowledge and skills in order to show the unity of practicality and aesthetics of arts and crafts design as much as possible. The second is regionality. Different geographical locations, different materials, different regional aesthetic styles, and different production and skills have resulted in different art crafts. For example, in Jingdezhen, because there is kaolin that can be used to make good porcelain, Jingdezhen is famous for its porcelain throughout the country. In Suzhou, silk cloth is only available because of the superior silk and female embroiders with superb embroidery skills, and Suzhou embroidery becomes famous all over the world. Because southeast area of Guizhou Province is the birthplace of many ethnic minority cultures, it has colorful costumes and accessories of various ethnic groups. Mr. Chen Zhifo believes that the nationality in the design represents the cultural customs and design manifestations of different nations. For example, there are the melon shell hat of Xinjiang Uyghur people, the Tibetan hada, and the Mongolian horse head string instrument and so on. China is a multi-ethnic unified country. Arts and crafts produced by regional, national or cultural differences are rich and colorful, and the categories are too numerous to enumerate, but no matter how differences vary, their essence is the unity of practicality and aesthetics.

\section{A CONTRIBUTOR TO THE DEVELOPMENT OF MODERN ART EDUCATION}

\section{A. Emphasizing the important impact of art education on life and society}

After returning from studying in Japan, Chen Zhifo taught for 40 years and was committed to art education, design education and design practice. In the 1920s and 1930 s, in that turbulent era of wars, and in the early stages of Chinese art education, Chen Zhifo almost went forward alone and dedicated his entire life to Chinese art education. He studied art education and design practice education all his life. He edited many masterpieces in arts and crafts, and published many newspaper articles on art, which also left many precious materials for Chinese art history. In the arts and crafts education and teaching, Chen Zhifo was influenced by Mr. Cai Yuanpei's new learning. He regarded "truth", "goodness" and "beauty" as the primary principles of aesthetic education and clarified the purpose of arts and crafts education. Advocating the all-round development of morality, intelligence physique and aesthetic has become the dominant aesthetic education for the motherland's youth. Chen Zhifo made a more detailed and profound analysis of the relationship between moral education, intellectual education, physical education and aesthetic education. Morality embodies moral character; moral education must be assisted by aesthetic education in order to give full play to its moral value and not become a mere formality; aesthetic education must have moral and intellectual education as the basis to enhance aesthetic appeal. The three complement each other and not a single one can be omitted.

\section{B. Respecting educational objects and carrying out scientific art education}

Chen Zhifo always respected the people-oriented view of education in art teaching activities. No matter how the social environment changed, he always held a humanistic spirit and was very active in teaching. Moreover, Mr. Chen Zhifo not only paid attention to the ideological education of young scholars in education, but also paid more attention to the issue of children's art education. Children are the hope for the future of the motherland. And different from the complex aesthetics of adults, Chen Zhifo believed that children had their own physical and psychological foundations, and children's aesthetic cognition determined that they were absolutely different from adults' aesthetic cognition. Chen Zhifo believed that in the teaching activities of cultivating children's aesthetic cognition, children's own psychological activities 
should be respected, and children's subjective aesthetic awareness should not be deprived of, and correct guidance should be provided on the basis of their aesthetic cognition to give full play to children's own subjective initiative and promote the scientific development of children's aesthetic cognition, which has a profound impact on their growth. Chen Zhifo not only respected educational objects, but also had a pair of eyes that are good at discovering geniuses. In 1946, in an examination conducted by the Ministry of Education to select overseas students with official fees, Chen Zhifo made a very high evaluation of a student's painting, and chose this student as the best candidate for studying abroad. This student was professor $\mathrm{Wu}$ Guanzhong, a famous painter who later became famous all over the world. Moreover, Chen Zhifo often gave his all to help his students. He often drew and sold paintings to raise funds for his students to go to other places for investigation. It is because of Chen Zhifo's selfless dedication to art education that many practical and capable art talents have been cultivated. In 1962, Chen Zhifo died of a sudden cerebral hemorrhage due to overwork as the editor-in-chief of the "Chinese Arts and Crafts History" textbook at the age of 66. It can be said that, in Chen Zhifo's not-so-long life, he devoted all his efforts to the cause of modern Chinese art education without any reservation, and cultivated artistic talents for the motherland without hesitation, therefore, he also created his unique lofty status in the history of modern Chinese art.

\section{CONCLUSION}

By analyzing Chen Zhifo's lifelong art learning and education contributions, it can be seen that Chen Zhifo occupies an important position in the history of modern Chinese art education and has a profound impact on the development of Chinese art education. He is a master with selfless dedication to art education in modern times. He not only made indelible contributions to the development of Chinese pattern design, but also made outstanding contributions to Chinese art history and art education. Chen Zhifo taught for more than 40 years. He selflessly devoted himself to the education of the motherland and published many articles on art education. At the same time, he cultivated a large number of outstanding art talents, which has promoted the continuous development of Chinese modern art education. He not only directly participated in art education activities, but also served as the school leader of different art schools for a long time. He also participated more in the discipline construction of art education and gradually improved the system of modern art education in China. Especially in the establishment of new majors suitable for social development, he made great contributions. While constantly improving himself, Chen Zhifo made continuous contributions to the development of national fine arts from a sense of social responsibility. This kind of spirit of thinking and acting for the entire nation's fine arts should be more impressive as a model for artists. History fades in time and space, but Mr. Chen Zhifo will never fade out of people's memory because of his historical position.

\section{References}

[1] CHEN xiufan, li youguang (Ed.). Chen zhifo collection [M] Jiangsu: jiangsu fine arts publishing house.1996.

[2] ZHANG daoyi. Collected works of zhang daoyi (volume 1) [M]. Anhui: anhui education press. 1999.

[3] WANG shouzhi. History of modern design in the world [M] Beijing: China youth press. 2002.

[4] WU guanzhong. My negative danqing [M]. Beijing: people's literature publishing house. 2004

[5] ZHANG xiaolu. Modern fine arts pedagogy [M]. Chongqing chongqing southwest normal university press. 2002.

[6] YANG yongshan. Central arts and crafts - collection of art design [M]. Beijing: Beijing arts and crafts press. 1996

[7] ZHANG daoyi. Inner gate [M]. Jinan: shandong fine arts publishing house. 2001

[8] CHEN zhifo. Pattern composition method [M]. Shanghai: Shanghai kaiming bookstore. 1937.

[9] ZHANG daoyi. The pattern heritage of Mr. Chen zhifu [M]. Xi 'an: shaanxi people's fine arts publishing house. 1986.

[10] JI ruxun. A brief history of Chinese handicraft industry [M] Beijing: contemporary China press.1998.

[11] XI chuanji. Selected works on design art [M]. Southeas university press.2001

[12] SUN qunhao. Chen zhifu biography [M]. Shanghai: Shanghai calligraphy and painting publishing house.2014

[13] ZHAO siyou. Chen zhifu's contribution to China's arts and crafts education $[\mathrm{J}]$. The hundred schools of art.2005.no.4:176 178.

[14] LONG hong. A study on educational thought in Chen zhifu's book [J]. Hundred schools of art.2006, no.6:140-144.

[15] LIU haiying, Chen liping. On Chen zhifu's outstanding contribution to Chinese arts and crafts education [J]. Archives expo.2014, no3:119-120

[16] LI youguang, tang lingjie. Mr. Chen zhifu as an art educator [J]. Journal of nanjing university of the arts.2006, no.2:123-125.

[17] WAN shuyuan. Chen zhifu's contribution to modern design [J] Journal of tongji university.2016, vol.27, no.2:71-76.

[18] Faye Dowling. The Book of Blacke [M]. Laurence King, 2017.

[19] Thames hudson.Crucial Intewentions:An illustrated Treati [M] Thames hudson. 2015

[20] Jean`Marie Le Minor. Atlas of Human Anatomy. 